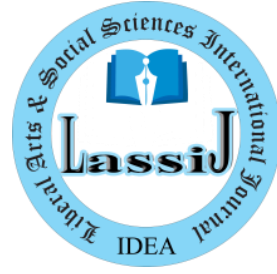

Research Article

ISSN: 2664-8148 (Online)

Liberal Arts and Social Sciences

International Journal (LASSIJ)

https: / / doi.org/10.47264/idea.lassij/3.2.3

Vol. 3, No. 2, (July-December) 2019, 20-34

https://www.ideapublishers.org/lassij

\title{
Afghan Peace Process and the Role of Pakistan in Engaging the Stakeholders
}

\author{
Muhammad Idrees ${ }^{1}$, Ashfaq U. Rehman ${ }^{2}$ and Manzoor Ahmad Naazer ${ }^{1 *}$
}

1. Department of Politics \& International Relations, International Islamic University, Islamabad Pakistan.

2. Department of Political Science, Faculty of Social Sciences, Women University Swabi, Pakistan.

\begin{abstract}
The Afghan people suffered a lot from war on terror, security issues, and political and economic instability since US invasion in 2001. Pakistan being an important neighbouring country of Afghanistan can play a vital role in bringing amity and stability through facilitating peace process. Both the US administration and Afghan government demand Pakistan to influence and bring the Taliban to the table talks. In this context, this study aims to explore Pakistan's role in the ongoing peace process that has so far created an understanding among the stakeholders that a peaceful and stable Afghanistan is in the interest of the region. The study finds that there are greater issues to be dealt with carefully e.g., the governance system of the country, the constitution, and a viable powersharing formula to be acceptable to all the stakeholders. Any successful peace deal needs a strong commitment on the part of all the stakeholders. Peace is the need of the hour not only for Afghanistan but for the whole region as well. Pakistan needs to continue her support to the Afghanistan's stability and play its due role in the peace negotiations in the greater regional interests.
\end{abstract}

Keywords: Peace, Reconciliation, Negotiations, Conflict Resolution, Regional Security.

\section{Introduction}

Washington and Taliban rapprochement when mediated by Pakistan would become fruitful only if the US administration fulfils their promise of minimising the number of foreign troops including US and NATO, in Afghanistan. The Taliban's entry into mainstream politics of Afghanistan would be only possible when the key security issues are dealt with wisely e.g., the power sharing mechanism, the future governmental structure and equal representation to the major sections in the Afghan parliament. If the internal stakeholders e.g., the Taliban, the insurgent groups, the war lords and the Kabul government are not ready to give room to each other then, the US and NATO forces' withdrawal would only add to severity of the already worse situation in Afghanistan and the region as well. The lack of an agreed peace settlement among all the stakeholders will ultimately result in another devastating civil strife which the neighbouring countries cannot welcome, especially Pakistan. Thus, Pakistan believes to play a middle role between both the external and internal stakeholders and make a negotiated settlement possible. Authorities in Islamabad are of the view that the success of any negotiated settlement would be possible only when it is owned and carried by the Afghanis themselves and is facilitated by the major external stakeholders. 


\section{Literature Review}

The United States (US) has been demanding Pakistan for long to take formidable actions against Taliban leadership and their sanctuaries. US administration has been pushing Pakistan for 'do more' since the Musharraf regime (Naazer, Mahmood, \& Ashfaq, 2017; Salim, Semetko, \& Zehraa, 2018). Moreover, the US also stresses upon Islamabad to play a key role in motivating the Taliban for peace talks. The US president Donald Trump initiating the "New Afghan Strategy" put Pakistan at the centre of the game. This strategy should be more practical only when Pakistan would take severe action against the terrorist to eliminate the Taliban sanctuaries (Kaura, 2018). Under the new policy, the US claims to be pushing Taliban insurgents through military pressure towards negotiations. The main challenge for Zalmay Khahlilzad, the US special envoy and chief negotiator of the Afghan peace process, is to influence the insurgents for a peace deal with the Kabul government. Nonetheless, the US gives high priority to a peace deal with the Taliban. It brought the Taliban towards negotiating table since last September to end the longest war of her history. The US hopes to be successful in making a deal with the Taliban before September 2019. The US Foreign Secretary Mike Pompeo had great certainty about it that he expressed during his visits. (The Express Tribune, 2019). But due to the Taliban's continuing suicide attacks, violence, and terror, the peace process was suspended.

It is an interesting situation as Pakistan has repeatedly announced that its leverage over the Taliban has declined due to different governmental actions such as labelling Taliban affiliates as terrorists and banning them. But the US denies this by putting so long as the Taliban leadership is inclined towards Pakistan, Islamabad would retain influence upon them. If the US is convinced by Pakistan's position and the role it plays for instilling peace to the war-torn country it will be a beneficial deal for Islamabad. On the contrary, the presence of Taliban leadership in Pakistan and their support looks such puzzles which Pakistan has ever denied. US President Trump asked Pakistan's Prime Minister Imran Khan to play a mediating role in the peace negotiations (Awan, 2019). Pakistan can improve her regional posture and reputation by making sincere efforts to bring the Taliban to a meaningful dialogue process including all Afghan internal and external stakeholders. But pressing for peace deal and taking tough military action against Taliban affiliates by US and NATO forces is hard to understand that how it will meet both ends?

The most important of all the peace initiatives underway is chalking out a working formula for power-sharing among the Afghan stakeholders. The policy wings are cautious about the US withdrawal amid the nascent peace process which may put the country into a new upheaval of civil mistrust. Afghanistan has become a battleground for regional rivalries and hasty US move from Afghanistan could generate another civil war and accelerate the regional power struggle. Thus, providing an opportunity to terrorists and insurgent groups to operate at a regional and global level according to their agenda - most fatal would be the rise of the Islamic State (ISIS) and al-Qaeda resurgence (Naazer, 2019). The High Peace Council (HPC), formed in 2010, was an initiative of President Hamid Karzai that offered the Taliban a good deal to remove their names from the blacklist if they abandon violence and their affiliation with al-Qaeda. But the group rejected the proposal and launched a fresh wave of terror and violence (Zaki, 2008). Marsden (2008) focused on the ethnic diversity of Afghan society and argued that for successful and result oriented negotiations the inclusion of tribal elders and ethnic elements would be helpful. 
The role of international humanitarian organisations in the peacebuilding programs has been increased since the cold war ended. They conduct different peace programs e.g., humanitarian assistance, poverty eradication, economic and social development (Fazly, 2016). Furthermore, democratic liberalism theory suggests that states having liberal democracies are more peaceful and vice versa. The theory further suggests that long term peace would require promoting liberal democratic values for sustaining peace (Naazer, 2018). However, Fazly (2016) suggests that this approach bore no fruits in Afghanistan. The Afghan peace process needs a viable strategy and clear agenda otherwise there seems no possibility for success and the history of such processes show failures (Qarqeen, 2015). The divisions within the Taliban ranks about the negotiation process and the presence of peace spoilers and fractional struggle all weaken the negotiations (Waldman, 2010). Kaura (2018) argues that the Afghan government since 2001 has tried to convince and bring the Taliban and insurgent groups to peace table and avoid further escalation of the conflict.

Though new deadline for furthering the peace process was not given yet the US authorities announced that they expect to get success towards a peace deal prior to the delayed presidential elections in Afghanistan. The Taliban who consider the Kabul government as a foreign puppet does not want to engage with them in any peace deal prior to the withdrawal of foreign forces. The US has been preparing itself to withdraw her forces but in a due and right time which has not been decided yet (The Express Tribune, 2019). Taliban also claim that unlike the past, they did not want a monopoly of power, because acquiring the whole country by force will not bring peace and stability to the country. Taliban did not want a complete "military" victory but want to find a solution through peaceful means and dialogue, with the aim that once the foreign forces are withdrawn there should be no intra-Afghan conflict so that a long-term peace could be established. Thus, it indicates that the Taliban may be willing to a power-sharing set up in a peaceful Afghanistan in the future (Khan, 2019).

\section{Methods and Material}

The current study presents a qualitative analysis of the available and relevant data on the issue. The issue of the Afghan peace process is thoroughly investigated with reference to Pakistan's role in the peace negotiations. The first section is introductory which gives and orientation about the study. The second section elaborates the available literature on the Afghan peace process, its success, and failure. The fourth section analyses the hurdles in the way of peace process e.g., the regional powers rivalries adding complexities to the process while for the success of the process the stakeholders need to compromise their agendas and at last this section proposes 'what would be a viable and workable peace strategy for Afghanistan? Moreover, this section elaborates Pakistan's role in the process and offers that Pakistan's role must be limited to that of a facilitator of peace and the process must be fully owned by Afghans themselves. Further, this section explores Pakistan's engagement in peace initiatives with regional and world powers. Finally, key findings and recommendations for the Afghan peace process are presented in the concluding section.

\section{Discussion and Findings}

\subsection{Hurdles to Peace in Afghanistan}

Though several rounds of peace negotiations which are held so far have brought some sort of understanding among the stakeholders for the peace process, yet the peace is still a far behind 
dream for the Afghanis. The process seeks to bring the militants to table-talks to give a guaranty that after the US withdrawal their territory would not be used by foreign militants. For peace and stability in Afghanistan, all the stakeholders must give up their myopic agendas and work together in a broader sense for the region. The US needs to understand the complexities of the region and make things correct with all major stakeholders including China and Iran. For Afghanistan itself, as for other regional partners, operationalisation of the TurkmenistanAfghanistan-Pakistan-India (TAPI) gas pipeline and a linkage between Chabahar Port and Gwadar Port, could offer positive outcomes (Idrees, Naazer, \& Rehman, 2017; Ali, 2019, June). Building confidence through economic linkages can bring positive results both for Afghanistan and the regional partners, thus will help to overcome hurdles in the peace process.

The death of Mullah Akhtar Mansoor caused a fatal blow to the peace process with the Taliban since Mullah Mansoor was said to be in favour of talks. Indeed, there has been the only political office of the Qatari Taliban who pledged their allegiance to Mullah Mansoor - that was engaged in negotiations convened by the US, China, Pakistan, and Afghanistan (Jeong, 2017). But the US president declared in a different tone that the death of Mullah Mansoor is an "important milestone" in the longstanding efforts to bring peace to Afghanistan (Zia, 2016). Prior to Mullah Mansoor's death in July 2015, Pakistan hosted a dialogue process between the Afghan government and Taliban representative. Senior officials from US, Pakistan and China also attended the meeting. It was a great move towards peace in Afghanistan which was backed by key international players. The death of Mullah Omar, the Taliban Chief, jeopardised the nascent process before its second round was held (Zia, 2016).

The Afghan government institutions have been not delivering good governance and bring social and political development to the country (Kaura, 2018). The stakeholders seem not very sincere in their efforts to install peace compromising their lofty goals. Thus, President Ashraf Ghani's earnest appeal to the parties involved to think of ending the war in Afghanistan, instead of winning it does not seem to cut ice under present circumstances (Vinay, 2018). The major powers' rivalry and presence of rival regional powers in Afghanistan multiply the complexities in the region. The erstwhile Soviet Union, and the United States, in today's context, has only served to legitimise the activities of the insurgents and jihadists across Afghan territory (Kaura, 2018; see Rehman, Rahman, \& Ali, 2018).

The US strategy of withdrawing thousands of their troops from Afghanistan and sending their top negotiator Mr. Khalilzad to set the table for talks shows that they have decided to give a better ending to their project in Afghanistan. The challenge now lies in finding a middle ground between the US and the Taliban on two issues. The first is presence of US forces in some, albeit limited capacity for anti-terror operations and the second is facilitating a successful dialogue between the Taliban, the Kabul government, and other Afghan stakeholders. These two issues have eluded agreement with the Taliban reiterating their position that the US remains an occupying force and that any discussions with other political stakeholders in Afghanistan would precede the finalisation of US forces' withdrawal from Afghanistan (Ahmad, 2019; Akbar, 2019).

The focus of the Taliban narrative is a ceasefire, complete withdrawal of the foreign troops from Afghanistan, a viable governance system, foreign guarantors of the peace deal, prisoners exchange, and lifting ban on Taliban leaders' movement. To Taliban, the complete US withdrawal from Afghanistan may reduce their role of a facilitator of peace process. The Americans accept that they have been defeated in Afghanistan and just want to extricate their 
troops safely (The Conversation, 2019). Therefore, US and NATO have been withdrawing their armed missions in an expected 18 months period (Ahmad, 2019). The US-Taliban talks in Qatar's capital, Doha as well as intra-Afghan dialogue involving the insurgents and some Afghan officials, are only the first phase of a complicated process with an uncertain outcome and there are many hurdles to overcome (Saifullah, 2019; Azami, 2019).

\subsection{Building Viable Strategy for Peace}

Whenever there is a step forward for the Afghan peace process there is an uncertainty that who should be, and who should not be included in the process? The question which arises here is who should be the main stakeholders? The more probable statement would be who are main partners of the Afghan peace process? A rare understanding suggests that the process must include all warring groups or to undermine the risk by excluding the rebel groups from the peace initiatives (Hartzell, 2014). A political solution to the conflict of Afghanistan must be Afghan-led but it must be supported internationally to build momentum and resilience (Hadley \& Kolenda, 2018). A peace deal to be successful needs the inclusion of all major partners because the process would be successful only when it is both 'led and owned' by Afghanis (Dawn, 2019). According to Hartzell (2014), the rebel groups were initially hesitant to become party to the peace deal. Later, they choose to do so because they were sure of benefits which other signatories to the deal will receive. Therefore, they are hopeful of the gains because, otherwise they could have lost the chance of taking benefits.

Analysis of the Afghan issue suggest the inclusion of youth and women into the peace process which can be useful for obtaining results. The country today presents a multitude of new realities that are important to understand. Having experienced an era of social transformation, 75 percent of the population is under the age of 35 year, have grown up in a democracy and have a different set of expectations and principles from those of their parents and grandparents. No doubt, the later were born in war and grew up in conflict or exile said, Hamdullah Mohib, the National Security Advisor of Afghanistan (Relief Web, 2019). The initiatives for mainstreaming Afghan youth and women into Afghan society by including them in peace jirga and other reconciliation meetings for Afghan peace have been appreciated by the world community. In December, the Afghan government hosted a Jirga including 2,500 young people of different social backgrounds from 34 provinces. Another similar meeting was held in which almost 3500 women participated and expressed their expectations from the peace process (Mahmood, Shaukatullah, \& Ashfaq, 2018; Azim, Mehmood, \& Hussain, 2018; Security Council, 2019).

Peace and disputes settlements do not happen overnight. NATO representative Mr. Nicholas Kay said it is a process that will require intra-Afghan talks and a multitude of voices to be heard, and level and number of troops depend on the progress and outcome of negotiations (The Frontier Post, 2019). The possibility to negotiate with insurgent groups in Afghanistan depend whether the current Taliban leadership can ensure that its various sub-groups and networks will comply with any settlement (Hartzell, 2014). The initiatives for peace which were carried on in the past reveal that there was a need of: a) long term commitment for the peace process, and; b) prioritizing efforts to coordinate strategies towards achieving a common political end (Hadley \& Kolenda, 2018). The consensus between the US and the Taliban for drafting a deal on key issues proves their intentions to continue the peace process until an acceptable deal is reached (Rashid, 2019). 
The Afghan peace process "must be fully Afghan-owned and Afghan-led," former President Hamid Karzai said at the $8^{\text {th }}$ World Peace Forum in China (Tolo News, 2019). He has also been stressing for transparency in the ongoing peace process to evolve results. In 2018, President Ashraf Ghani announced a one-sided truce with the Taliban to make them realise that their activities are damaging the nation which the Taliban responded positively, and to the surprise of all, and they also observed a ceasefire against Afghan security forces during Eid holidays (Shah, 2019). But the year 2019 did saw no ceasefire despite the ongoing negotiation process. The Taliban leader Mullah Akhundzada in his Eid message said that no one should expect us to pour cold water on the heated battlefronts of ongoing jihad (Shah, 2019). The early failures of the peace processes are due to a lack of understanding of the core issue as well as a popular support. The process must accompany all the major segments of society and their grievances such as security, politics, economic, territory and identity must be addressed accordingly (Relief Web, 2012).

The agenda of the Afghan peace process would focus on consensus on countering the terrorism, withdrawal of the US and NATO forces, Intra-Afghan negotiations, and a complete ceasefire. Once a dialogue will be underway, there are a number of models for inclusion of the stakeholders in the peace process. Various effective models have been employed by other countries in such issues which could be adapted for the Afghan context as well (Hartzell, 2014). The models include:

- The Liberian peace Model (which enabled the government to reach a peace deal with the rebels)

- The Mali Model (direct, traditional, and local level peace process)

- Inter-Tajik Dialogue (a consultative forum of Tajikistan's people for implementing the peace agreement)

There may initially be a need for secrecy and confidentiality on the part off all stakeholders. It may be appropriate to initiate a broadly inclusive process once, a dialogue has been established among the opposing factions (Hartzell, 2014). The contemporary security situation of the country exposes the complications in government vs. Taliban peace process. Moreover, "the optimistic and oblivious government behaviour is a huge contradiction with ground realities" (Rehman, 2014). The Afghan peace process is progressing well yet has been in the initial stages. Ambassador Khalilzad expressed at the US Institute of Peace, "we have a long way to go" (Gallagher, 2019).

\subsection{Pakistan's Commitment to the Peace Process}

Pakistan has always supported all initiatives taken towards peace in Afghanistan. Pakistan considers a peaceful and prosperous Afghanistan key to the prosperity of the region. The longevity of the Afghan conflict is not in the interests of any stake holder (both internal and external). The neighbouring countries being located within proximity with conflicting zone are at high risk. Talking about this Pakistan's Foreign Minister Mr. Qureshi told that "instability in Afghanistan is impacting both Islamabad and Kabul" (The News International, 2019, October). Afghanistan can play the role of facilitator for transit trade in the region. The Belt and Road Initiative (BRI) and China Pakistan Economic Corridor (CPEC) that aims to provide the facility of transit trade to China, Afghanistan, and Central Asian Republics (CARs) would only be possible if there is peace and harmony in Afghanistan (Rehman, Hakim, Khan, \& Khan, 
2018; Muzaffar, Yaseen, Rahim, 2017). The regional rivalries need to be eased by increasing regional level interdependence. The interdependence would further help the Afghan government to stabilize its economy through new avenues of finance generation. Thus, the government will be able to give more livelihood options to the masses including the ones dependent on opium production and "war economy" (Ali, 2019, June).

War is not a solution to any dispute or a conflict. Therefore, Pakistan believes in meaningful dialogues between the major stakeholders to bring about an end to the regional conflicts (Zikriya, Khan, \& Salim, 2019). Making peace with Taliban has been considered a major challenge for the Kabul government. However, Pakistan's mediating role at this stage is seen crucial by the Afghan government and all major stakeholders (Tahir, 2019). Pakistan has been trying to convince the Taliban leadership that continuing violence is not helpful in confidence building with the US. Islamabad also praised the release of senior Taliban leaders from Bagram prison and called it a great confidence building measure. As a response the Taliban have been told to set free three Indian engineers abducted from the northern Baghlan province (Tahir, 2019). Pakistan considers these peace gestures as a great move for peace in Afghanistan. Pakistan's positive role in the process gives it a greater opportunity to send a message to US authorities that she wants a peaceful region and a healthy neighbourhood.

Prior to the recent engagement between Pakistan and Afghanistan regarding peace deal with the Taliban following the Afghan presidents' request to Islamabad to play its role in the process, the relations were deteriorated due Pakistan's Premier Khan remarks regarding the establishment of interim government because of the failure of the Ghani government (Noori, 2019). However, after recent developments, the US state department appreciated Pakistan's involvement in the process saying that Pakistan could play a positive role in peace building in Afghanistan (Iqbal, 2019). Pakistan's authorities have reassured their commitment to play a positive role in the Afghan peace process. Our country is resolute towards finding a reliable solution to the conflict because Pakistan wants Afghanistan "at peace with itself" said Foreign Minister Qureshi (Pakistan Today, 2019). Pakistan's foreign office spokesman highlighting Pakistan's role in the process told that his country would continue to facilitate the process yet it supports "politically negotiated intra-Afghan solution to the problem" (The News International, 2019, July). Pakistan has been playing a key role in peace process as it has considerable influence over Afghan Taliban. The Afghan president Ashraf Ghani attending a seminar in Islamabad offered a suggestion, "recognising all important things we must work on programmatic approaches moving from conflict to cooperation" (Gul, 2019). Pakistan's role as a facilitator of the US-Taliban dialogue and her overall performance has also been praised by the President Trump. Inviting Pakistan's Premier Khan to the US is indicative of positive gestures and augurs well for the region (Masood, 2019).

\subsection{Pakistan's Engagement with Regional Stakeholders for Afghan Peace}

The key foreign partners in the peace process must be the US, China, Russia, and Pakistan. Iran and India have also greater interests in Afghanistan but currently, India has announced to remain outside the process and Iran due to US and Iran rivalry has been kept out of the process. In November 2018, India participated in the peace conference initiated by Russia in Moscow as a non-official delegate. Her representative expressed that India was following a policy of supporting a solution to the conflict which would be "Afghan-led, Afghan-owned and Afghan controlled" including the Afghan government (Saberin \& Qazi, 2018). The perceived hasty withdrawal of foreign forces and quickness in the peace process by the US and Russia to end 
the long-lasted conflict has left India in a quandary. India has long been suspicious about the Taliban return to power in Kabul because she fears that under such a scenario the militants may invariably shift their ground to India and Indian occupied Kashmir (D’Souza, 2019). India's reluctance to engage with Taliban not only jeopardises its long-term interests in the country but also "puts it at odd" with the world community (Mitra, 2018).

India has been a signatory of the 2018 Tashkent Agreement which proposed an Afghan initiated peace process. But the process did not include the Taliban directly neither India was directly engaged with them. The Taliban have been expanding its network of friendly countries in the region and are no more in isolation. They have been active at the diplomatic front from its Qatar office having established contacts with friendly countries which includes their former adversaries e.g., Iran, Russia and India who were not favouring them during 1990s (Mitra, 2018). Iran strives to build contacts with the Taliban, and it has a key role to play in making a peace deal with the insurgent groups. Several rounds of talks have taken place between the Taliban envoys and Iranian authorities. In Tehran, a meeting was held amid the rumours of the US taking out its seven thousand troops from Afghanistan. The Trump administration wants a steady exit to achieve its political outcomes at home. It has already made few hasty moves e.g., withdrawal from Iran's nuclear deal, cancelling the Paris Climate Change Agreement and decision to move the US embassy from Tel Aviv to the Jerusalem (Rehman, 2019, April).

The elderly politician and president of ANP a nationalist political party recommended that all potential stakeholders should be included as a party to the Afghan peace process (Rehman, 2019, January). In his tone, "I think Afghanistan, I think China, I think the United States, I think many countries can do to encourage the Taliban to come to the negotiating table, I think the peace process has to end up at some point in time," said Campbell (Gul, 2019). Thus, all stakeholders must play a constructive role pushing aside their lofty ambitions of downplaying each other. In fact, there was a dire need for the establishment of a multilateral peace council by regional countries including China, Pakistan, Iran, and Russia to find a solution to the conflict through dialogue. The power struggle between regional states in Afghanistan so far is preventing such things. "The blame game between Kabul and Islamabad combined with trust deficit between the US and Russia, and the US and Iran has prompted them to talk on their own which has led to nowhere" (Sultan, 2019; Zia, 2018, August). Meanwhile, Kabul's ties with its neighbours such as China, Iran, and Pakistan, "are still weighed down heavily" by securityrelated issues, including; the smuggling of illicit goods and services; cross-border terrorism, and; the consequent "threats to the safety of foreign citizens residing in and traveling to Afghanistan" (Ali, Ali, \& Ullah, 2019; Jan 2019).

\subsubsection{China and Pakistan}

China and Pakistan are the most resolute peace supporters in the region. They also wish to push the Taliban to the table talk. Apart from this, China supports the Kabul government politically and diplomatically at international and regional gatherings. Dr. Zeng of Sichuan University said that he does not think China being able to bring the Taliban to the negotiating table, but Pakistan has leverage over the Taliban (Zia, 2018, August). The Kabul government called upon China and Pakistan to become partners in the peace process. The Kabul government welcomes all regional and international efforts for peacebuilding and counterinsurgency (Gul, 2019). The peacebuilding process requires active diplomacy which China as a regional giant has the potential to play. China has so far played a key role in counter-terrorism and counterinsurgency efforts in the region. The Chinese initiative for developing counter-terrorism 
consensus between regional countries and her efforts for 'Quadrilateral Cooperation and Coordination Mechanism' (QCCM) to countering terrorism have been highly appraised (Jianing, 2016).

China's BRI project including the CPEC can be highly significant in promoting interdependence and facilitating transit trade to Afghanistan and CARs through the open seaports of Pakistan (Khatoon, Rahim, \& Ali, 2018). The effects of the US led war or terror has generally "overshadowed many attempts by its neighbours to meaningfully engage in major trade, investment and/or development related activities" (Jan, 2019). The BRI project is vital for regional development through trade interdependence but is viable only when there is peace in Afghanistan (Gul, 2019). China has gradually cultivated good ties with the Taliban since the Moscow meeting. She looks at her peacebuilding steps in Afghanistan as easing the terrorist threats from Afghanistan thus boosting her own economic projects (Stone, 2019). The Chinese regional connectivity projects such as the BRI is a glaring example of her interest and willingness to play an important part in the Afghan peace process (Jan, 2019).

\subsubsection{Russia and Pakistan}

Pakistan welcomed the Russian role in the Afghanistan peace process though the US does not appreciate such moves either from Russia or China. Pakistan considers Russia as a major power and one of the most powerful regional players in the Afghan peace process (Ali, 2019, February). The Pakistan Foreign Ministry reiterated their commitment to work with Russia on their format of a peace deal agreed upon during the meeting of Pakistan's Foreign Minister and Russian envoy last month (Ali, 2019, February). Pakistan attended the last November meeting called by Russia with the support of Iran and China which though was not much successful yet provided an opportunity to make an understanding of the issue. There is a growing realization within and amongst Afghanistan's immediate neighbours, such as Pakistan, Iran, Russia, China, and the CARs that the region can no longer solely depend on the international community, and that it is time for them to take ownership of the region and fend for themselves by overcoming their differences, build positive relations and a common vision for the region, and more so, for Afghanistan (Khan, 2019).

Russia admired Pakistan's facilitating role in the ongoing Afghan peace process. The Washington based observers consider Pakistan's role in the process up to the extent to influence the group to stay connected with US officials in Doha. They envisaged the Prime Minister Imran Khan's visit to Washington nothing more than Pakistan's support for the peace process (Iqbal, 2019). The Russian envoy to Afghanistan Mr. Kabulov referring to Russia-Pakistan coordination in the Afghan peace process said that "both are important partners to the peace process and stability of Afghanistan" (Daily Times, 2019). Pakistan and Russia's recent engagement in terms of the Afghan peace process is a hallmark achievement of Pakistan's foreign policy in posturing Pakistan as a peace-loving country. Both countries consider the positive role of regional countries for peacebuilding in Afghanistan. Pakistan gives equal weight to Moscow format of consultation and the foreign ministry praised the contribution which Russia makes in the Afghan peace process (Daily Times, 2019).

\subsubsection{Quadrilateral Coordination Group}

The Quadrilateral Coordination Group (QCG) was formed in December 2015 to push forward the peace process with the Taliban. The group includes US, Afghanistan, China, and Pakistan. 
Commenting on Mullah Mansoor's death, Zia (2018) holds that the drone strike against the Taliban leader in the Balochistan province of Pakistan prior to the second round of talks with the Taliban created mistrust between Pakistan and the US. Thus, the incident sabotaged the second round of the process with the Taliban. While the QCG referred to the violence continuing amid the process urged for direct talks between the government and the Taliban (Khalil, 2019). The move was welcomed by the Afghan government and there were great hopes for peace talks with the insurgents. However, little progress was seen due to the Taliban's refusal to attend the peace table.

The analysts consider that China can play a mediator role in convincing Pakistan to seriously get engage with the Taliban and make things move forward. The recent policy of the UN and the US has been to support the Afghan government in her peace initiatives with the Taliban for ensuing a viable process (Munshey, 2016). The peace initiatives by the QCG so far are away from any good outcome due to US dual policy towards peace process and combating the insurgents. The QCG efforts bore fruits by bringing together the member countries e.g., Afghanistan, the US, China, and Pakistan to cooperate and understand each other's diplomacy on the subject (Munshey, 2016).

\section{Conclusion}

There seems a big trust-deficit between the internal stakeholders of the Afghan peace process e.g., the Kabul government, the Taliban, and the elites. So, there is dire need to remove the trust deficit among the internal stakeholders of the peace process. The involvement of external stakeholders is the key for establishing peace in Afghanistan. However, the insurgents do not fully consider the US very sincere in her peace initiative and are thus reluctant to wholeheartedly join the peace initiatives. So, there is a need on the part of the US to show her sincerity in the peace process. Confidence building is the need of the hour. The guarantors of peace need to play a middle role to convince the conflicting parties, and Afghan and US authorities to an equally beneficial deal for all striving sections of Afghanistan who want peace. Regional stakeholders must be included in the process and their steps for peace must be encouraged. Iran is a key stakeholder in the process and ignoring it cannot bring favourable effects on the peace process. The group initiatives for peace e.g., QCG and other similar setups must also coordinate their efforts for a viable solution of the issue. There is maximizing support for the slogan; "the Afghan peace must be Afghan-owned." Mr. Karzai the former president and all prominent analysts support the maxim for peace. So, the external stakeholders must play a facilitating role by providing opportunities for the varying Afghanistan internal stakeholders to get together and discuss their issues.

Pakistan must play key role in Afghanistan's peace and stability. Her role needs to be accepted by all stakeholders both internal and external. However, Pakistan's facilitating role must also be coordinated with China and Russia for maximizing the outcome of the process for peacebuilding and all must play their role up to their maximum extant. The most important of all is the US role and her commitment to peace. Because she is the driver of peace in Afghanistan, so she needs to drive carefully taking all the important stakeholders to the main direction and achieve the goal. Another important question is the US troop's withdrawal from Afghanistan. Their exit must be dealt with according to a given timeframe which should be agreed upon by all the stakeholders. The problems of the governance system and constitution must be dealt with great care and collaboration of main internal stakeholders. The Afghans must decide their future themselves. Peace gesture e.g., ceasefire, releasing the prisoners of 
war and lifting bans on Taliban leaders, all helps in building confidence among the stakeholders. Such steps have been encouraged by regional players, the international community and even the insurgent groups which shows their seriousness towards the Afghan peace process.

\section{References}

Ahmad, J. (2019, January 8). Afghan Taliban cancel peace talks with U.S. citing 'agenda disagreement'. Retrieved from RUETERS: https://www.reuters.com/article/us-usaafghanistan-taliban/afghan-taliban-cancel-peace-talks-with-u-s-citing-agendadisagreement-idUSKCN1P20BL

Akbar, H. (2019, January 25). Timeline of US Taliban Talks. Retrieved from Jinnah Institute: https://jinnah-institute.org/opinions/timeline-of-us-taliban-talks

Ali, R. Ali, I. \& Shaukatullah (2019). Shanghai Cooperation Organization as a passage to regional security: Future developments and opportunities for Pakistan. Liberal Arts and Social Sciences International Journal (LASSIJ), 3(1), 19-29.

Ali, S. (2019, February 7). Pakistan supports Russia's role on Afghan peace. Retrieved from The Nation: https://nation.com.pk/07-Feb-2019/pakistan-supports-russia-s-role-onafghan-peace

Ali, S. M. (2019, June 28). Peace prospects in Afghanistan. Retrieved from The Express Tribune: https://tribune.com.pk/story/2001639/6-peace-prospectsafghanistan/?amp=1

Awan, Z. A. (2018, December 7). Pakistan key to Afghan peace process. Retrieved from China Daily:

http://www.chinadaily.com.cn/a/201812/07/WS5c0a09eda310eff30328fc05.htm

Azami, D. (2019, July 14). Afghanistan war: What could peace look like? Retrieved from BBC News: https://www.bbc.com/news/world-asia-47733079

Azim, S. W., Mehmood, W. \& Hussain, S. (2018). Swat Conflict in Retrospect: Violence and Jarga among the Swat Pukhtuns in Pakistan. Liberal Arts and Social Sciences International Journal (LASSIJ), 2(1): 37-48.

Council, S. (2019, March 11). Success of Afghanistan peace process will depend on international support for local efforts, Special Representative tells Security Council. Retrieved from Relief Web: https://reliefweb.int/report/afghanistan/successafghanistan-peace-process-will-depend-international-support-local-efforts

Dawn (2019, July 14). Afghan peace. Retrieved from Dawn. Available at; https://epaper.dawn.com/DetailImage.php?StoryImage=14_07_2019 $008 \quad 001$

Daily Times (2019, January 30). Russia and Pakistan key stakeholders in Afghan peace: Envoy. Retrieved from Daily Times: https://dailytimes.com.pk/349323/russia-and-pakistankey-stakeholders-in-afghan-peace-envoy/

D'Souza, M. (2019, March 18). The limits of India's soft power in Afghanistan. Retrieved from Fair Observer: https://www.fairobserver.com/region/central_south_asia/afghanistantaliban-peace-talks-india-south-asia-security-news-00081/

Fazly, H. (2016, December). The deadlock of Afghan peace process. Master Arts Thesis, International Institute of Social Studies, Hague. Retrived from Semantic Scholar:https://pdfs.semanticscholar.org/5983/723f857baedfdd6df3754d588e915a6 5dece.pdf.

Gallagher, A. (2019, February 11). Progress in Taliban talks, but 'long way to go', says US envoy. Retrieved from United Institute of Peace: 
https://www.usip.org/publications/2019/02/progress-taliban-talks-long-way-gosays-us-envoy

Gul, A. (2019). Afghanistan stakeholders push diplomacy. Retrieved from Small Wars Journal: https://smallwarsjournal.com/blog/afghanistan-stakeholders-push-diplomacy

Gul, A. (2019, April 28). Pakistan: Afghan peace to boost China-funded regional connectivity effort. Retrieved from VOA News: https://www.voanews.com/south-centralasia/pakistan-afghan-peace-boost-china-funded-regional-connectivity-effort

Gul, A. (2019, June 28). Ghani seeks Pakistan's support for Afghan peace talks with Taliban.

Retrieved from VOA News: https://www.voanews.com/south-central-asia/ghaniseeks-pakistans-support-afghan-peace-talks-taliban

Hadley, E., and Kolenda, C. D. (2018, June). Political process in Afghanistan: What role for international partners? Retrieved from Conciliation Resources: https://www.c$\underline{\text { r.org/accord/afghanistan/political-process-afghanistan-what-role-international- }}$ partners.

Hartzell, C. A. (2014, December). A comparative perspective on an Afghan peace process: why, when, who and what? Report on Afghanistan: Opportunity in Crisis Series No. 7. Retrieved from Chatham House: https://www.chathamhouse.org/sites/default/files/field/field_document/20141204Af ghanPeaceProcessHartzell.pdf

Idrees, M., Naazer, M. A., \& Rehman, A. U. (2017). Conflict and conflict management in SAARC. Liberal Arts and Social Sciences International Journal (LASSIJ), 1(2): 111.

Iqbal, A. (2019, July 13). US, Russia, China recognise Pakistan's role in Afghan peace process. Retrieved from Dawn: https://www.dawn.com/news/1493775

Jan, W. (2019, January 31). China's role in brokering peace in Afghanistan. Retrieved from Pakistan Today: https://www.pakistantoday.com.pk/2019/01/31/chinas-role-inbrokering-peace-in-afghanistan/

Jeong, M. (2017, January 19). Afghan Peace Talks. Retrieved from Pulitzer Center: https://pulitzercenter.org/projects/afghan-peace-talks

Jianing, Y. (2016, August 4). Afghanistan, China, Pakistan, Tajikistan issue joint statement on anti-terrorism. Retrieved from Chian Mail: http://english.chinamil.com.cn/newschannels/china-military-news/2016-08/04/content_7191490.htm

Kaura, V. (2018, April). Understanding the complexities of the Afghan peace process. ORF Occasional Paper No. 151, retrieved from Observer Research Foundation: https://www.orfonline.org/wpcontent/uploads/2018/04/ORF_Occasional_Paper_151_Afghanistan.pdf

Khalil, A. B. (2019, April 12). The Afghan National Unity Government's 'China Card' approach to Pakistan: Part 2. Retrieved from The Diplomat: https://thediplomat.com/2019/04/the-afghan-national-unity-governments-chinacard-approach-to-pakistan-part-2/

Khatoon, A., Rahim, N., \& Ali, B. (2018). A historical perspective of China's peaceful policies and its rise as world economic power. Liberal Arts and Social Sciences International Journal (LASSIJ), 2(1), 65-74.

Khan, A. (2019, February 26). The Afghan peace process and the role of Moscow. An Issie Brief of Institute of Strategic Studies Islamabad, edited by Najam Rafique. Retrieved from: http://issi.org.pk/wp-content/uploads/2019/02/IB_Amina_Feb_26_2019.pdf 
Mahmood, A., Shaukatullah, \& Ashfaq, S. (2018). The evolution of jirga system: A conflict resolution mechanism in FATA. Liberal Arts and Social Sciences International Journal (LASSIJ), 2(1), 21-28.

Marsden, P. (2008). Whither the Taliban. Asian Affairs, 39(3), 362-369.

Masood, T. (2019, July 3). Regional efforts for peace in Afghanistan. Retrieved from The Express Tribune: https://tribune.com.pk/story/2004817/6-regional-efforts-peaceafghanistan/?amp=1

Mitra, J. (2018, November 2). Should India talk to the Taliban? Retrieved from TRT World: https://www.trtworld.com/opinion/should-india-talk-to-the-taliban-21322

Munshey, M. (2016, March 10). An incoherent push for peace in Afghanistan. Retrieved from LSE Blogs on South Aisa: http://eprints.lse.ac.uk/74646/1/blogs.lse.ac.ukAn\%20incoherent\%20push\%20for\%20peace\%20in\%20Afghanistan.pdf

Naazer, M. A. (2018). Islamic universalism and the nation state. Liberal Arts and Social Sciences International Journal (LASSIJ), 2(2), 29-41.

Naazer, M. A. (2019). Nationalism in the Muslim world: A curse or blessing? Liberal Arts and Social Sciences International Journal (LASSIJ), 3(1), 30-42.

Naazer, M. A., Mahmood, A., \& Ashfaq, S. (2017). Political rights situation during Musharraf era: 1999-2004. Liberal Arts and Social Sciences International Journal (LASSIJ), l(1), 20-31.

Noori, H. (2019, March 29). Pakistan PM's remarks on Afghan peace process stir diplomatic row. Retrieved Al-Jazeera News: https://www.aljazeera.com/news/2019/03/pakistanpm-remarks-afghan-peace-process-stir-diplomatic-row-190328115121755.htm

Pakistan Today (2019, June 22). Pakistan supports an Afghanistan that is at peace with itself, says Qureshi. Retrieved Pakistan Today: https://www.pakistantoday.com.pk/2019/06/22/afghan-peace-conference-lahoreprocess-starts-in-bhurban/

Qarqeen, F. (2015). Afghan Peace Talks: Negotiating with the Taliban. PhD Thesis submitted to American University of Centeral Asia, Bishkek: http://elibrary.auca.kg/bitstream/123456789/2333/1/FRESHTA\%20QARQEEN.pdf

Rashid, A. (2019, March 13). Is an Afghan peace deal finally within grasp? Retrieved from Al-Jazeera News: https://www.aljazeera.com/indepth/opinion/afghan-peace-dealfinally-grasp-190313155343638.html

Rehman, A. (2014). Peace talks with Taliban: Expectations, realities and way. A Research Journal of South Asian Studies, 29(1), 197-205.

Rehman, A. U., Rahman, B. \& Ali, T. (2018). US war on terror: Portrayal through caricatures in selected newspapers of Pakistan. Pakistan Journal of Criminology, 10(3), 41-63.

Rehman, A. U., Hakim, A., Khan, K., \& Khan, I. U. (2018). Role of CPEC in development of trade, transport, and economy of Pakistan. Romanian Journal of Transport Infrastructure, 7(1), 77-92.

Rehman, N. (2019, April 10). Understanding key stakeholders in Afghan peace process. Retrieved from Balochistan Voices: http://balochistanvoices.com/2019/04/understanding-key-stakeholders-in-afghanpeace-process/

Rehman, S. U. (2019, January 10). All stakeholders should be made part of Afghan peace process. Retrieved from Business Recorder: https://www.brecorder.com/2019/01/10/464522/all-stakeholders-should-be-madepart-of-afghan-peace-process-asfandyar-wali/ 
Relief Web (2012). Afghanistan: Pathways to peace. Retrieved from Relief Web: https://reliefweb.int/sites/reliefweb.int/files/resources/Afghanistan\%20Pathways\%2 0to\%20peace.pdf.

Saberin, Z., and Qazi, S. (2018, November 8). Afghan peace conference: India shares table with Taliban. Retrieved from Al-Jazeera News: https://www.aljazeera.com/news/2018/11/afghan-peace-conference-india-sharestable-taliban-181109092419577.html

Saifullah, M. (2019, July 9). Were Afghan peace talks in Qatar a success? Retrieved from DW: https://www.dw.com/en/were-afghan-peace-talks-in-qatar-a-success/a-49527086-0.

Salim, A. Semetko, H. A., \& Zehraa, S. (2018). Pak-US Strategic Partnership and Challenge of Internal Radical Symbiosis. Liberal Arts and Social Sciences International Journal (LASSIJ), 2(1), 57-64.

Shah, K. M. (2019, June 13). The problem with the Afghan peace process. Retrieved from Observer Research Foundation: https://www.orfonline.org/expert-speak/theproblem-with-the-afghan-peace-process-51986/.

Stone, R. (2019, July 19). Slowly but surely, China is moving into Afghanistan. Retrieved from TRT World: https://www.trtworld.com/magazine/slowly-but-surely-china-ismoving-into-afghanistan-24276.

Sultan, T. (2019, January 8). Peace in Afghanistan joint responsibility of all regional stakeholders: Analysts. Retrieved from Radio Pakistan: http://www.radio.gov.pk/0801-2019/peace-in-afghanistan-joint-responsibility-of-all-regional-stakeholdersanalysts

Tahir, M. (2019, October 9). News analysis: As major stakeholder in Afghan peace process, Pakistan mediating for resumption of U.S.-Taliban talks. Retrieved from NEWS Xinhua Net: http://www.xinhuanet.com/english/2019-10/09/c 138458244.htm.

The Conversation (2019, February 4). Afghanistan: the tensions inside the Taliban over recent US peace talks. Retrieved The Conversation: http://theconversation.com/afghanistanthe-tensions-inside-the-taliban-over-recent-us-peace-talks-110734

The Express Tribune (2019, June 25). Pompeo hopes for Afghan peace deal 'before September 1'. Retrieved from The Express Tribune: https://tribune.com.pk/story/2000160/3pompeo-hopes-afghan-peace-deal-september-1/

The Frontier Post (2019, March 25). NATO, allies support Afghan peace process. Retrieved from The Frontier Post: https://thefrontierpost.com/nato-allies-support-afghanpeace-process/

The News International (2019, July 11). Pakistan's facilitatory role in Afghan peace process earning wide appreciation: FO. Retrieved from The News International: https://www.thenews.com.pk/latest/496957-pakistans-facilitatory-role-in-afghanpeace-process-earning-wide-appreciation-fo

The News International (2019, October 3). Pakistan playing an honest role in Afghan peace process: FM Qureshi. Retrieved from The News International: https://www.thenews.com.pk/latest/535760-pakistan-playing-an-honest-role-inafghan-peace-process-qureshi.

Tolo News (2019, July 10). Peace process should be fully Afghan-owned: Karzai. Retrieved from Tolo News: https://www.tolonews.com/afghanistan/peace-process-should-befully-afghan-owned-karzai

Vinay, K. (2018, April 26). Understanding the complexities of the Afghan peace process. Retrieved from Observer Research Foundation: 
https://www.orfonline.org/research/understanding-the-complexities-of-the-afghanpeace-process/

Waldman, M. (2010). Tough talking: The case for negotiations with the Taliban. The RUSI Journal, 155(6), 60-66.

Zaki, M. M. (2018, November). A study of Afghan peace process. A pre-print, retrieved from ResearchGate:https://www.researchgate.net/publication/330704171_The_Peace_Pu zzle_A_Study of_Afghanistan_Peace_Process

Zia, H. (2016, May 24). The impact of Mansour's death on peace talks. Retrieved from Daily Outlook Afghanistan: http://outlookafghanistan.net/topics.php?post_id=15339.

Zia, H. (2018, August 20). Involving stakeholders key to Afghan peace talks. Retrieved from the China Daily: http://global.chinadaily.com.cn/a/201808/20/WS5b7a0251a310add14f38692d.html

Zia, H. (2018, November 4). Regional stakeholders should involve in Afghan peace process. Retrieved from Daily Outlook Afghanistan: http://www.outlookafghanistan.net/topics.php?post_id=22144.

Zikriya, Khan, N. \& Salim, A. (2019). Middle East dilemma: Pakistan's role as mediator for conflict resolution. Liberal Arts and Social Sciences International Journal (LASSIJ), $3(1), 9-18$. 